\title{
Effect of inclusion of pentasulphate mixture and arsenic in diets given high level of selenium on feed intake and nutrient utilization in buffaloes
}

\author{
Ajay Kumar ${ }^{1}$, Chander Datt ${ }^{2}$, Sonali Prusty ${ }^{3}$, SS Kundu $^{4}$ and Veena Mani ${ }^{5}$
}

Received: 29 September 2019 / Accepted: 04 October 2019 / Published online: 31 December 2019

(C) Indian Dairy Association (India) 2019

\begin{abstract}
Sixteen male Murrah buffalo calves were divided into 4 groups with 4 animals in each group based on their body weight and age. The animals were fed on rations to supply $15 \%$ less of $\mathrm{CP}$ requirements as per NRC (2001). All the animals were fed a basal diet $(0.41 \mathrm{ppm} \mathrm{Se})$ comprising of paddy straw, concentrate mixture and green maize (Control, group $\mathrm{T}_{1}$ ). The animals in groups $\mathrm{T}_{2}, \mathrm{~T}_{3}$ and $\mathrm{T}_{4}$ were also supplemented with $10 \mathrm{ppm}$ of $\mathrm{Se}$ in the form of sodium selenite. After $60 \mathrm{~d}$ of feeding, animals in groups $\mathrm{T}_{3}$ and $\mathrm{T}_{4}$ were given supplementary arsenic (40 ppm of diet) in form of sodium arsenite and pentasulphate mixture $(9 \mathrm{~g} / 100 \mathrm{~kg}$ $\mathrm{BW})$, respectively in addition to $\mathrm{Se}(10 \mathrm{ppm})$ being already given. After 85 days of feeding, a metabolism trial was conducted in order to determine DM intake, nutrient digestibility and balances of N and Se. DM Intake was similar in all the groups. Digestibility of nutrients (DM, OM, EE and NDF) and nitrogen retention was also not affected by dietary treatments to any significant extent, however, digestibility of $\mathrm{CP}$ and $\mathrm{ADF}$ was lower $(\mathrm{P}<0.05)$ in group $\mathrm{T}_{2}$ compared to other groups. Supplementary pentasulphate mixture and As increased excretion of Se which paved the way for its less retention $(\mathrm{P}<0.01)$ in the body. Hence, supplementation of either pentasulphate mixture @ $9 \mathrm{~g} / 100 \mathrm{~kg} \mathrm{BW}$ or arsenic (40 $\mathrm{ppm}$ ) to the diet already supplied with extra $10 \mathrm{ppm}$ Se improved the digestibility of $\mathrm{CP}$ and $\mathrm{ADF}$ while reducing the Se load from the body considerably showing the positive effect of arsenic and pentasulphate supplementation in buffalo calves given high level of Se in paddy straw based rations.
\end{abstract}

\footnotetext{
${ }^{1}$ Govt. Poultry Farm, Sundervani, Rajouri, Jammu \& Kashmir, India

${ }^{2}$ Animal Nutrition Division, ICAR-National Dairy Research Institute, Karnal-132001, Haryana, India

${ }^{3}$ College of Veterinary Science and AH, Chhattisgarh Kamdhenu Vishwavidyalaya-491001, Durg, Chhattisgarh, India

$4 \& 5$ Animal Nutrition Division, ICAR-National Dairy Research Institute, Karnal-132001, Haryana, India

Chander Datt $(\bowtie)$

Animal Nutrition Division, ICAR-National Dairy Research Institute, Karnal-132001, Haryana, India

Email: chandatt@gmail.com
}

Keywords: Arsenic, Buffalo, Nutrient Utilization, Pentasulphate mixture, Selenium

\section{Introduction}

Selenium (Se) is an essential trace element for all the categories of livestock and its deficiency results in poor health and production. About 30 selenoproteins have been identified which play important biochemical and physiological functions (Hefnawy and Tórtóra-Perez 2010). Nutritional requirement of Se in ruminants is $0.3 \mathrm{ppm}$ (NRC 2001). On the other hand, chronic selenosis in form of Degnala disease has been reported in buffaloes. Selenosis in the form of Degnala disease affects this species leading to deterioration in health and production status. Cases of Degnala disease have been reported in buffaloes fed mainly on paddy straw containing high levels of Se particularly in Punjab, Haryana, Uttar Pradesh (Arora et al. 1975; Bakshi et al. 1986). The maximum tolerable level of Se is $5 \mathrm{ppm}$ (NRC 2005).

The mechanism of action of chronic Se toxicity involves displacing sulphur from S-containing amino acids like methionine and cysteine. Dietary Se level affects feed intake, microbial protein synthesis and nutrient utilization adversely (Khirwar and Arora 1976, Bakshi et al. 1986). Both sulphur (S) and arsenic (As) are antagonist to Se (Sun et al. 1988; Zeng et al. 2005; Gailer et al. 2000; Pilsner et al. 2011) which could be used to alleviate chronic selenosis. The cases of Degnala disease in buffaloes have been successfully treated using pentasulphate/Degcure mixture based on antagonistic relationship between Se and S (Arora et al. 1975). Therefore, the effects of supplementation of $S$ (pentasulphate mixture) and As on feed intake and nutrient utilization were studied in male buffalo calves given high level of Se in the diet.

\section{Materials and Methods}

\section{Experimental animals and their feeding}

Sixteen male Murrah buffalo calves were selected from ICARNational Dairy Research Institute herd and divided into 4 groups of 4 animals each based on body weight (136.50 36.05 , $134.50 \pm 24.52,133.75 \pm 33.23$ and $133.50 \pm 37.45 \mathrm{~kg}$ in groups $\mathrm{T}_{1} \mathrm{~T}_{2}$, $\mathrm{T}_{3}$ and $\mathrm{T}_{4,}$ respectively) and age $(11.14 \pm 1.80,11.11 \pm 2.40,11.08 \pm 2.98$ 
and $10.96 \pm 2.74$ mon.). The animals were fed on rations to supply $15 \%$ less of protein and TDN requirements as per NRC (2001). The initial body weights of animals were similar in all the groups. All the animals were fed a basal diet $(0.41 \mathrm{ppm} \mathrm{Se})$ comprising of paddy straw, concentrate mixture and green maize. The concentrate mixture comprised (\% parts) maize grain 33, groundnut cake 21 , mustard cake 12 , wheat bran 20 , rice bran 11 , mineral mixture 2 , common salt 1 . Chaffed paddy straw, maize fodder and concentrate mixture were fed as total mixed rations in the ratio of 50: 20: 30. The animals in groups $\mathrm{T}_{2}, \mathrm{~T}_{3}$ and $\mathrm{T}_{4}$ were supplemented with $10 \mathrm{ppm}$ of Se in form of sodium selenite until blood Se level approached $1.5 \mathrm{ppm}$ which happened at $60 \mathrm{~d}$ of feeding. Thereafter, animals were given supplementary arsenic (40 ppm of diet) in form of sodium arsenite and pentasulphate mixture $(9 \mathrm{~g} / 100 \mathrm{~kg} \mathrm{BW})$ in groups $\mathrm{T}_{3}$ and $\mathrm{T}_{4}$, respectively in addition to $\mathrm{Se}(10 \mathrm{ppm})$ being already given. The animals were provided clean and fresh water ad lib. twice a day throughout the study.

\section{Metabolism trial}

A metabolism trial was conducted after $85 \mathrm{~d}$ of initiation of the experiment to study feed intake, digestibility of nutrients and balances of nitrogen and Se. During the trial, samples of feeds, refusals, water, faeces and urine were collected daily and pooled separately for each animal. The feed, residues and faecal samples were dried $\left(70^{\circ} \mathrm{C}\right)$ for $48 \mathrm{~h}$ and ground to pass through $1 \mathrm{~mm}$ sieve. The retention of Se was determined by subtracting the total amount of mineral excreted in urine and faeces from the amount of mineral ingested while the amount of mineral absorbed was calculated as the difference between the dietary intake and faecal excretion.

\section{Analytical procedures}

Proximate analysis of feeds and faeces and $\mathrm{N}$ in urine was carried out (AOAC 2005). Fibre fractions were estimated (Van Soest et al. 1991). The levels of Se in feeds, refusals, water, faeces and urine were analysed using atomic absorption spectrophotometer (Hitachi-5000 Z Series) equipped with hydride generation facility (HGAAS) while As and sulphur contents in feeds, refusals and water were estimated using HGAAS and turbiditimetric method (Massoumi and Cornfield 1963), respectively.

\section{Statistical analysis}

The data were analysed statistically using one-way analysis of variance (ANOVA) as per Snedecor and Cochran (2007). Differences between the mean values of the different groups were considered significant at $\mathrm{P}<0.05$.

\section{Results and Discussion}

\section{Feed intake}

The chemical composition as well as the Se, As and S contents of the feeds and fodders are provided in Table 1. The chemical composition of the feeds and fodders was similar throughout the experimental period. The dietary concentration of Se in groups $\mathrm{T}_{1} \mathrm{~T}_{2}, \mathrm{~T}_{3}$ and $\mathrm{T}_{4}$ was $0.40,10.25,10.32$ and $10.43 \mathrm{ppm}$, respectively with corresponding values of $0.17,0.16,40.26$ and $0.17 \mathrm{ppm}$ for As and $0.16,0.16,0.16$ and $0.23 \%$ for $\mathrm{S}$. The average DMI in groups $\mathrm{T}_{1} \mathrm{~T}_{2}, \mathrm{~T}_{3}$ and $\mathrm{T}_{4}$ was $2.93 \pm 0.09,3.02 \pm 0.16,2.98 \pm 0.17$ and $2.94 \pm 0.22 \%$ BW, respectively. Bakshi et al. (1986) reported significant depression in DM consumption in buffalo calves given urea treated paddy straw containing $2.14 \mathrm{ppm}$ Se as compared to those given urea treated wheat straw $(0.21 \mathrm{ppm} \mathrm{Se})$. Such a response could probably be due to differences in the forms of dietary Se. In their study, the intake of Se was mainly through

Table 1 Chemical composition of feeds ( $\%$ on DM basis)

\begin{tabular}{lllc}
\hline Parameter & Paddy straw & Maize fodder & Concentrate mixture \\
\hline Proximate composition & & & 22.14 \\
DM & 93.21 & 92.0 & 92.14 \\
OM & 84.06 & 6.9 & 92.02 \\
CP & 4.03 & 1.31 & 21.66 \\
EE & 1.13 & 29.39 & 3.73 \\
CF & 33.46 & 8.0 & 6.92 \\
Total ash & 15.94 & & 7.98 \\
Cell wall constituents & & 60.51 & 35.51 \\
NDF & 66.75 & 34.9 & 12.16 \\
ADF & 40.21 & 26.87 & 7.57 \\
Cellulose & 28.40 & 3.15 & 2.46 \\
Lignin & 4.95 & & 0.2 \\
Minerals & & 0.14 & 0.37 \\
S $(\%)$ & 0.15 & 0.46 & 0.21 \\
Se (ppm) & 0.50 & 0.13 & \\
As (ppm) & 0.20 & & \\
\hline
\end{tabular}


organic forms (NRC 1983) which might have depressed rumen microbial activity (Tekchandani and Arora 1978; Hansard 1983) while the inorganic Se formed the major part of dietary Se in this study. They also observed decreased digestibility of nutrients which in turn might have affected DM intake. Serra et al. (1994) also did not observe any difference in DM intake on supplementing $0.2 \mathrm{ppm}$ inorganic Se in sheep given basal diet containing $31.74 \mathrm{ppb}$ of Se, however, the overall dietary Se level in their diets was just adequate. Both deficiency and excess of Se in the diet affected feed intake in birds (Bunk and Combs 1980) and excess of $\mathrm{Se}$ in the diet reduced $\mathrm{DM}$ intake in ruminants (Bakshi et al. 1986). Supplementation of 0.3-0.4 ppm of Se to Se deficient diets increased DM intake and feed efficiency in cattle (Bonomi 2001).

\section{Digestibility of nutrients}

The animals in group $\mathrm{T}_{2}$ showed lower $(\mathrm{P}<0.05) \mathrm{CP}$ and ADF digestibility as compared to groups $\mathrm{T}_{1} \mathrm{~T}_{3}$ and $\mathrm{T}_{4}$ indicating that pentasulphate mixture and arsenic had positive effect on digestibility of these two chemical constituents in the diets of animals given additional $10 \mathrm{ppm}$ Se (Table 2). As per NRC (1980), the maximum tolerable limit of $\mathrm{Se}$ for dairy cattle is $2 \mathrm{ppm}$. Arora et al. (1975) reported occurrence of selenosis in the form of Degnala disease on feeding rice straw containing 0.9 to $6.7 \mathrm{ppm}$ Se. Prasad and Arora (1984) and Bakshi et al. (1986) revealed occurrence of Degnala disease on feeding rice straw with $3.45 \mathrm{ppm}$ and 2.14 ppm Se, respectively. Therefore, the dietary Se levels in groups $\mathrm{T}_{2}, \mathrm{~T}_{3}$ and $\mathrm{T}_{4}$ were considered high. Selenium tolerance by the animals depends on several factors (NRC 1983; Mc Dowell 1992). Harrison and Conrad (1984) did not find any significant difference in the DM digestibility of Holstein cows where the intake of Se varied from 400-3100 ig/d. Chander Datt and Chhabra (2006) reported no significant effect on the digestibility of proximate principles in buffalo calves given a supplementary level of 2.7 ppm inorganic Se to the basal diets containing $0.5 \mathrm{ppm}$ Se. The digestibility of DM, CP, OM and NDF was not affected in sheep supplemented with organic or inorganic Se $(0.12 \mathrm{mg} / \mathrm{head} /$ day $)$ as compared to control group ( $0.144 \mathrm{ppm} \mathrm{Se})$. However, Serra et al. (1994) reported that supplementing the basal diet (31.74 ppb $\mathrm{Se}$ ) with $0.2 \mathrm{ppm}$ inorganic Se slightly reduced fibre digestion and tended to increase protein digestion. They opined that alteration in nutrient digestibility could be due to complicated adjustment in rumen because of dietary Se. When given urea treated paddy straw (2.14 ppm Se), Bakshi et al. (1986) found significant reduction in digestibility of nutrients (DM, OM, CP, EE, NFE, NDF, ADF and cellulose). The depressed nutrient digestibility might due to high Se intake which has been reported to depress the rumen microbial activity (Tekchandani and Arora 1978; Hansard 1983, Chander Datt et al. 2013). The discrepancy among the studies might be partly due to differences in chemical forms and levels of dietary Se. An increase in digestibility and utilization of nutrients was recorded in cows supplemented with $0.2-0.3 \mathrm{ppm}$ of Se to the diets having deficient levels of Se (Vladimirov et al. 2003, Nadarinskaya 2003). Supplementation of diet with Se-yeast at low level improved rumen fermentation and feed digestion (Wang et al. 2009). The high level of Se in the supplemented group reduced digestibility of CP and ADF (Table 2). In vitro studies of Martinez and Church (1970) showed slight reduction in cellulose digestion when the level of Se in the incubation medium ranged from 0.01 to 5 ppm but significant reduction was observed when the level varied from 7 to $20 \mathrm{ppm}$. Selenium level of more than $12 \mu \mathrm{g} / 200 \mathrm{mg}$ substrate showed the inhibitory effect on true OM digestibility, in vitro gas production, microbial biomass production and total volatile fatty acids. Addition of As at 10 or $20 \mu \mathrm{g}$ level to the substrate $(200 \mathrm{mg})$

Table 2 Digestibility of nutrients and nitrogen balance in different groups of buffalo calves

\begin{tabular}{|c|c|c|c|c|}
\hline \multirow[t]{2}{*}{ Attribute } & \multicolumn{4}{|c|}{ Group } \\
\hline & $\mathrm{T}_{1}$ & $\mathrm{~T}_{2}$ & $\mathrm{~T}_{3}$ & $\mathrm{~T}_{4}$ \\
\hline \multicolumn{5}{|l|}{ Digestibility coefficient (\%) } \\
\hline DM & $62.23 \pm 2.08$ & $60.43 \pm 2.50$ & $60.65 \pm 1.90$ & $61.23 \pm 1.60$ \\
\hline $\mathrm{OM}$ & $64.34 \pm 1.67$ & $62.67 \pm 2.44$ & $59.28 \pm 1.90$ & $63.41 \pm 2.35$ \\
\hline $\mathrm{CP}$ & $69.17^{\mathrm{a}} \pm 1.08$ & $62.19^{b} \pm 2.99$ & $65.90^{a} \pm 1.74$ & $67.64^{a} \pm 1.83$ \\
\hline $\mathrm{EE}$ & $69.85 \pm 3.01$ & $65.49 \pm 4.48$ & $65.55 \pm 1.16$ & $65.89 \pm 2.08$ \\
\hline $\mathrm{NDF}$ & $56.49 \pm 2.30$ & $54.88 \pm 3.66$ & $56.32 \pm 2.43$ & $55.82 \pm 2.57$ \\
\hline $\mathrm{ADF}$ & $53.54^{\mathrm{a}} \pm 2.90$ & $48.23^{b} \pm 2 . .65$ & $51.32^{\mathrm{a}} \pm 1 . .42$ & $51.14 \pm 2.79$ \\
\hline \multicolumn{5}{|l|}{ Nitrogen balance } \\
\hline Total N intake $(\mathrm{g} / \mathrm{d})$ & $68.12 \pm 11.95$ & $66.34 \pm 9.61$ & $71.10 \pm 10.91$ & $67.66 \pm 13.66$ \\
\hline Faecal $\mathrm{N}$ excretion $(\mathrm{g} / \mathrm{d})$ & $21.0 \pm 3.42$ & $23.84 \pm 3.52$ & $24.14 \pm 4.59$ & $21.89 \pm 4.02$ \\
\hline $\mathrm{N}$ absorbed (g/d) & $47.17^{\mathrm{a}} \pm 2.17$ & $42.50^{b} \pm 1.30$ & $46.86^{a} \pm 1.53$ & $45.77^{\mathrm{a}} \pm 1.24$ \\
\hline $\mathrm{N}$ absorbed (\% of intake) & $69.17^{\mathrm{a}} \pm 1.08$ & $62.19^{b} \pm 2.99$ & $65.90^{a} \pm 1.74$ & $67.64^{a} \pm 1.83$ \\
\hline Urinary excretion (g/d) & $32.59 \pm 2.68$ & $30.75 \pm 2.64$ & $33.4 \pm 3.28$ & $33.02 \pm 1.62$ \\
\hline $\mathrm{N}$ retained $(\mathrm{g} / \mathrm{d})$ & $14.58 \pm 3.31$ & $13.75 \pm 2.98$ & $13.46 \pm 2.67$ & $12.75 \pm 2.75$ \\
\hline $\mathrm{N}$ retention ( $\%$ of intake) & $21.39 \pm 0.61$ & $18.73 \pm 1.05$ & $18.93 \pm 0.77$ & $18.84 \pm 0.42$ \\
\hline
\end{tabular}

${ }^{a, b}$ Values bearing different superscripts in a row differ significantly $(\mathrm{P}<0.05)$ 
containing $12 \mu \mathrm{g}$ Se improved rumen fermentation parameters under in vitro system, however, further addition of As $(40,80$ or $100 \mu \mathrm{g})$ showed negative effects on these parameters. (Chander Datt et al. 2013). Further, As and Se share many chemical properties, however, both have marked differences in their biological effects (Csanaky and Gregus 2003). Arsenic might decrease the toxicity of Se by combining with it in gastrointestinal tract, thereby, decreasing the absorption of the element. Both Se and As have been reported to increase biliary excretion of each other (Levender 1977; Pilsner et al. 2011). Arsenic and Se are antagonistic to each other and form a complex called seleno-bis ( $S$-glutathionyl) arsinium ion [(GS2AsSe]- which is secreted through bile and finally excreted through faeces (Gailer 2009). Sulphur (S) and Se are antagonist i.e. S either reduces tissue uptake of $\mathrm{Se}$ or increases its excretion from the body or both (Arora et al. 1975; Sun et al. 1988).

\section{Nitrogen and Se balance}

The average total $\mathrm{N}$ intake was similar in four groups (Table 2). The values for $\mathrm{N}$ absorbed $(\mathrm{g} / \mathrm{d})$ was lower $(\mathrm{P}<0.05)$ in group $\mathrm{T}_{2}$ as compared to other groups. Bakshi et al. (1986) reported higher $\mathrm{N}$ excretion through faeces and urine in male buffaloes calves resulting in negative $\mathrm{N}$ balance. Similar digestibility values were obtained when pentasulphate mixture and arsenic were added to high Se diets.

The dietary Se level in groups $\mathrm{T}_{1}, \mathrm{~T}_{2}, \mathrm{~T}_{3}$ and $\mathrm{T}_{4}$ was found to be $0.40,10.25,10.32$ and $10.43 \mathrm{ppm}$, respectively (Table 3 ). There were significant $(\mathrm{P}<0.01)$ differences among the groups with regard to Se intake, faecal excretion, apparent absorption, urinary excretion and net retention. The intake of Se by animals in group $T_{1}$ was just above the required level of $0.3 \mathrm{ppm}$ (NRC 2001) while the levels in other 3 groups were above maximum tolerable limits of 5 ppm (Mc Dowell 1992; NRC 2001). Chronic selenosis as 'Degnala disease' in buffaloes has been reported on feeding rice straw having 0.9 to $6.7 \mathrm{ppm}$ of Se (Arora et al. 1975) or rice husk with $6.23 \mathrm{ppm}$ of Se (Prasad et al. 1982) or rice straw containing 2.14 ppm of Se (Bakshi et al. 1986). Faecal Se excretion differed significantly $(\mathrm{P}<0.01)$ among groups. Faecal Se was the lowest $(1.11 \mathrm{mg})$ in group $\mathrm{T}_{1}$. Supplementation of As $\left(\mathrm{T}_{3}\right)$ and pentasulphate mixture $\left(\mathrm{T}_{4}\right)$ increased faecal excretion of Se when

Table 3 Absorption and excretory patterns of Se in different groups

\begin{tabular}{lllll}
\hline Particular & \multicolumn{3}{c}{ Group } \\
\cline { 2 - 4 } & $\mathrm{T}_{1}$ & $\mathrm{~T}_{2}$ & $\mathrm{~T}_{3}$ & $48.39^{\mathrm{b}} \pm 6.19$ \\
Total intake (mg) & $1.86^{\mathrm{a}} \pm 0.34$ & $47.66^{\mathrm{b}} \pm 1.84$ & $49.43^{\mathrm{b}} \pm 5.89$ & $42.20^{\mathrm{b}} \pm 5.45$ \\
Faecal excretion (mg) & $1.11^{\mathrm{a}} \pm 0.19$ & $37.94^{\mathrm{b}} \pm 1.5$ & $43.66^{\mathrm{b}} \pm 5.22$ & $6.19^{\mathrm{c}} \pm 0.76^{\mathrm{y}}$ \\
Apparent absorption (mg) & $0.75^{\mathrm{a}} \pm 0.14$ & $9.72^{\mathrm{b}} \pm 0.46$ & $5.77^{\mathrm{c}} \pm 0.71$ & $12.81^{\mathrm{c}} \pm 0.40$ \\
Apparent absorption (\%) & $40.34^{\mathrm{a}} \pm 0.79$ & $20.40^{\mathrm{b}} \pm 0.71$ & $11.68^{\mathrm{c}} \pm 0.48$ & $3.04 \mathrm{~b}^{\mathrm{c}} \pm 0.29$ \\
Urinary excretion (mg) & $0.19^{\mathrm{a}} \pm 0.03$ & $3.50^{\mathrm{b}} \pm 0.26$ & $2.57^{\mathrm{c}} \pm 0.46$ & $3.15^{\mathrm{c}} \pm 0.60$ \\
Retention (mg) & $0.56^{\mathrm{a}} \pm 0.11$ & $6.22^{\mathrm{b}} \pm 0.23$ & $3.20^{\mathrm{c}} \pm 0.32$ & $6.50^{\mathrm{c}} \pm 0.58$ \\
Retention (\% of intake) & $29.91^{\mathrm{a}} \pm 0.72$ & $13.05^{\mathrm{b}} \pm 0.49$ & $6.47^{\mathrm{c}} \pm 0.22$ & \\
\hline
\end{tabular}

a,b,c Values bearing different superscripts in a row differ significantly $(\mathrm{P}<0.01)$

Table 4 Plane of nutrition of the animals in different treatments

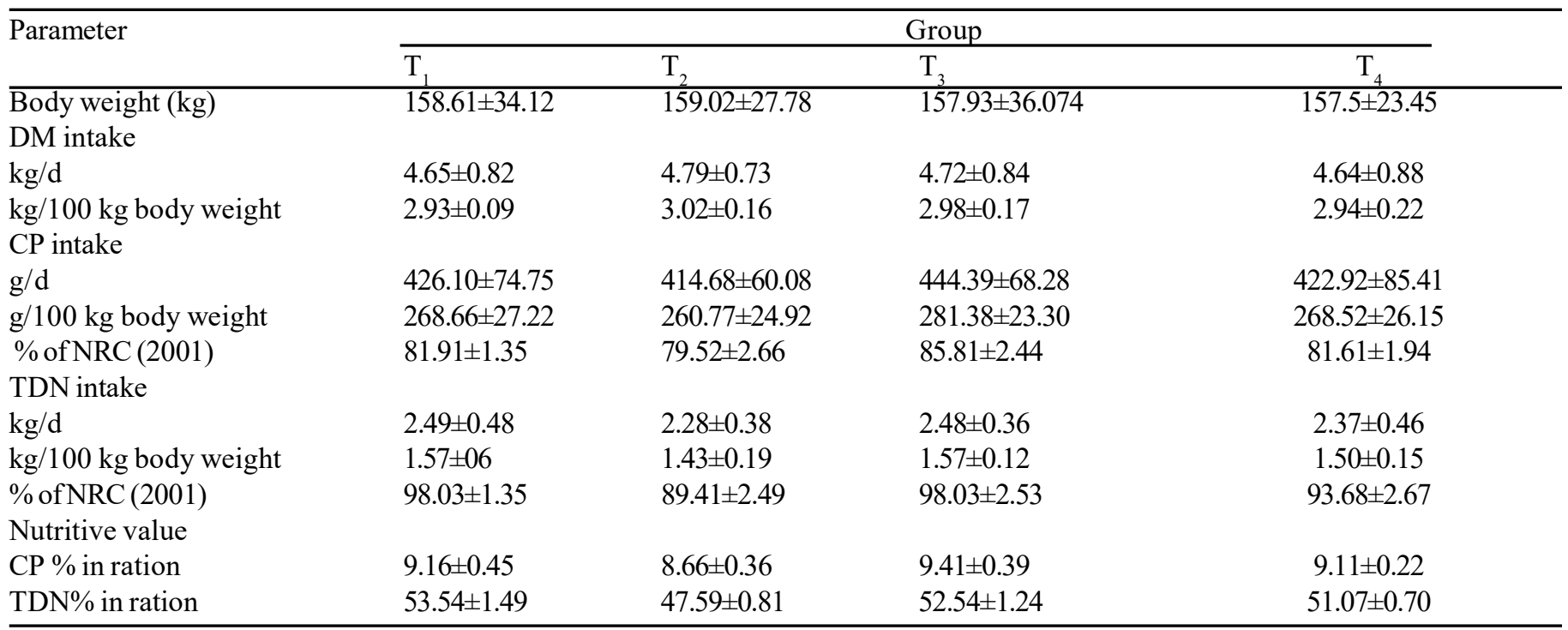


compared to group $\mathrm{T}_{2}$. Consequently, apparent absorption (mg/ $\mathrm{d}, \%$ of intake) was more in group $\mathrm{T}_{2}$ as compared to groups $\mathrm{T}_{3}$ and $\mathrm{T}_{4}$. Data on excretion of Se through faeces indicated that the major portion of ingested Se was excreted through faeces (Langlands et al. 1986, Serra et al. 1994, Krishnamurthi et al. 1997). The higher faecal excretion resulting in lower absorption might be due to the fact that rumen microbes convert much of dietary Se to insoluble forms, e.g. elemental Se, metal selenides (Durand and Kawashima 1980, Harrison and Conrad 1984; Hakkarainen 1993) which is not absorbable because it gets adsorbed to indigestible feed particles and then passed out of the gastrointestinal tract alongwith faeces (Podoll et al. 1992). Rumen also provides a very strong reducing environment which may convert ingested Se to reduced forms which are not available for absorption (Durand and Kawashima 1980; Van Saun 1990) and this type of conversion is more when high concentrate diets are fed (NRC 1983; Gerloff 1992). Organically bound Se is rendered unavailable to a lesser extent as compared to the inorganic $\mathrm{Se}$ (NRC 1983; Peter and Whanger 1986). Apparent absorption of Se averaged $40.34,20.40,11.68$ and $12.81 \%$ in groups $\mathrm{T}_{1}, \mathrm{~T}_{2}, \mathrm{~T}_{3}$ and $\mathrm{T}_{4}$, respectively. Apparent absorption ranging from 17 to $64 \%$ has been reported in ruminants supplemented with sodium selenite (Harrison and Conrad 1984; Zanetti and Pettinati 1991; Aspila 1991). Another study (Bakshi et al. 1986) showed the apparent absorption of 96 and $57 \%$ in male buffaloes given lowSe urea treated wheat straw and high Se $(2.14 \mathrm{ppm})$ urea treated $(0.21 \mathrm{ppm})$ paddy straw, respectively. The apparent absorption of Se in wethers given Timothy hay alone containing $31.74 \mathrm{ppb}$ Se or supplemented with $0.2 \mathrm{ppm}$ inorganic Se was 67.39 and $74.32 \%$, respectively (Serra et al. 1994). Koenig et al. (1991) in studies with dairy cows given $0.19 \mathrm{ppm}$ Se diets, however, observed apparent absorption value of $3 \%$ only. The apparent Se absorption rate was significantly higher in the Se-yeast $(0.3$ $\mathrm{ppm})$ group (62\%) than in sodium selenite supplemented $(0.3$ ppm) lambs $(49.6 \%)$ or in those fed the unsupplemented basal $\operatorname{diet}(52.9 \%, \mathrm{P}<0.001)$. Due to lower absorption rate. the rams given sodium selenite had higher faecal Se excretion than the Seyeast fed animals whereas no differences between the supplemented groups appeared in urinary Se excretion (Greskova et al. 2013). The differences in absorption of Se from the digestive tract could be due to variations in composition of the rumen microbial population and the diet, chemical form and amount of dietary Se, Se status of animals (Hakkarainen 1993; Koenig et al. 1997) and other interacting factors in feeds like high dietary S, $\mathrm{Ca}$, As etc. reduced the bioavailability of Se (Spears 2003; Chander Datt et al. 2013).

It was clear that supplementation of arsenic and pentasulphate mixture reduced absorption of Se. Interacting factors like S, As and others have been reported to decrease the absorption of Se (Levander 1977; NRC 1980; Peter et al. 1982; Gailer et al. 2000). Urinary excretion of Se $(\mathrm{mg} / \mathrm{d})$ increased in Se supplemented groups. At higher level of intake, body tends to excrete the element through all its channels in order to get rid of excess supply to maintain a homoeostatic control and avoid toxicity. Therefore, urinary excretion of Se increased as the intake was increased (Fisher et al. 1980; Harrison and Conrad 1984). It has been demonstrated in rats that Se is excreted mainly in the form of trimethyl selenium $\left(\mathrm{TMSe}^{+}\right)$. Sanz-Alaejos and Diaz-Romero (1993) were of the view that TMSe though a minor metabolite of Se in urine at low Se intakes occupied a significant role in detoxification of excess Se intake. Ganther and Hseih (1974) have proposed a scheme of metabolic events involved in the excretion of Se in which glutathione (GSH), glutathione reductase and Sadenoyl methionine (SAM) as methyl group donor are actively involved in its excretion through urine mainly as $\mathrm{TMSe}^{+}$(trimethyl selenide) during chronic selenosis or mainly as dimethyl selenide during acute selenosis conditions. Therefore, deficiency of either GSH or glutathione reductase or SAM or all of these is likely to hamper the detoxification process in conditions of excess Se load. In the present study, the excretion of Se through urine was found to be higher $(\mathrm{P}<0.01)$ in high Se groups which could have been facilitated by liver SAM by providing methyl group through methyl transferases and finally its excretion in urine mainly as $\mathrm{TMSe}^{+}$. However, Se retention was higher $(\mathrm{P}<0.01)$ in high $\mathrm{Se}$ groups which indicated that detoxification was not complete and that the rate of entry of Se into liver might have exceeded the rate at which SAM was synthesised by liver cells. Therefore, liver cells might not be able to cope up with the Se methylation process for rapid excretion resulting in higher retention. Additional selenite has been shown to inactivate the methionine-adenosyl transferase enzyme system and this inhibition might have prevented replenishment of SAM. Prasad and Arora (1991) observed significantly lower concentration of SAM in the liver and GSH concentration in erythrocyte in buffalo calves administered either with selenite or selenomethionine compared to the control group.

Retention of Se differed $(\mathrm{P}<0.01)$ among the groups. Though the total amount of Se retained increased in groups $\mathrm{T}_{2}, \mathrm{~T}_{3}$ and $\mathrm{T}_{4}$ when compared to control $\left(\mathrm{T}_{1}\right)$ group but when expressed as percent of intake, the retention values were lower in high Se groups indicating that an inverse relationship existed between Se retention and intake of Se. Both retention and intake of Se are related linearly at dietary Se levels from deficient to adequate (Harrison and Conrad 1984) above which relationship becomes inverse (Lopez et al. 1969; Kinkaid et al. 1977). Further, retention of Se by buffaloes was lower in groups $\mathrm{T}_{3}$ and $\mathrm{T}_{4}$ compared to that in group $T_{2}$ indicating that As and pentasulphate mixture were capable of getting rid of extra Se supply by the animals because of their antagonistic relationship with Se (Whanger 1970; Arora et al. 1975; Levander 1977; NRC 1980; NRC 1983; Peter et al. 1981; McDowell 1992; Gailer et al. 2000).

\section{Plane of nutrition}

Mean CP intake was found to be $426.10,414.68,444.39$ and 422.92 $\mathrm{g} / \mathrm{d}$ in groups $\mathrm{T}_{1}, \mathrm{~T}_{2}, \mathrm{~T}_{3}$ and $\mathrm{T}_{4}$, respectively (Table 4) The CP 
intake was $14.19-20.48 \%$ lower when compared to the requirements (NRC 2001) of CP by cattle of similar body weight. This was evident because the animals in all the groups were offered rations containing $15 \%$ less $\mathrm{CP}$ than their requirements. These differences could be due to higher growth rate $(400 \mathrm{~g} / \mathrm{d})$ assumed as per recommendation of NRC (2001) whereas under present set of conditions the growth rate was lower (251.4 \pm 17.55 , $255.2 \pm 23.3,253.3 \pm 27.8$ and $249.5 \pm 24.3 \mathrm{~g} / \mathrm{d}$ in respective groups) since the animals were not maintained to achieve higher growth rate as paddy straw itself constituted more than $50 \%$ of total dietary DM. Likewise, deficit in TDN intake was 7-11\% less when compared to the recommendations of NRC (2001).

\section{Conclusions}

Supplementation of $10 \mathrm{ppm}$ Se to the control diet $(0.41 \mathrm{ppm} \mathrm{Se})$ did not affect feed intake and $\mathrm{N}$ retention, however, digestibility of $\mathrm{CP}$ and $\mathrm{ADF}$ was reduced $(\mathrm{P}<0.05)$ in buffalo calves. Supplementation of either pentasulphate mixture @9 g/100 kg $\mathrm{BW}$ or arsenic $(40 \mathrm{ppm})$ to the diet already supplied with extra 10 ppm Se improved the digestibility of CP and ADF while reducing the Se load from the body to a significant extent.

\section{Acknowledgements}

Authors are thankful to the Director, ICAR-National Dairy Research Institute, Karnal for providing necessary facilities to carry out this research work.

\section{References}

AOAC (2005) Official Methods of Analysis. Association of Official Analytical Chemists, Washington, D.C., USA

Arora SP, Kaur P, Khirwar SS, Chopra RC, Ludri RS (1975) Selenium levels in fodders and its relationship with Degnala disease. Indian J Dairy Sci 28: 249-253

Aspila P (1991) Metabolism of selenite, selenomethionine and feed incorporated selenium in lactating goats and dairy-cows. J Agric Sci Finland 63:69-74

Bakshi MPS, Langar PN, Rana RP, Katyal JC (1986) Selenosis in buffaloes fed rice straw. World Rev Anim Prod 22: 57-62

Bonomi A (2001) Selenium integration of rations for young bulls. Rivista di Scienza Alimentazione 30:233-246

Bunk MJ, Combs CF (1980) Effect of selenium on appetite in selenium deficient chicks. J Nutr 3:53

Chander Datt, Chhabra A (2006) Effect of selenium supplementation on feed intake and nutrient utilization in cattle and buffaloes. Indian J Anim Sci 76:955-960

Chander Datt, Ajay Kumar, Kundu SS. 2013. Effect of different levels of added selenium without or with arsenic on rumen fermentation parameters in buffaloes under in vitro conditions. Indian J Anim Sci 83:1203-1206

Csanaky I, Gregus Z (2003) Effect of selenite on the disposition of arsenate and arsenite in rats. Toxicol 186: $33-50$

Durand M, Kawashima R (1980) Influence of minerals in rumen microbial digestion. In: Y. Ruckebusch and P. Thivend (Ed.). Digestive Physiology and Metabolism in Ruminants. MTP Press Ltd., Lancaster, England. pp 375-408
Fisher I J, Hoggendoorn C, Montemurro J (1980) The effect of added dietary selenium on the selenium content of milk, urine and faeces. Can J Anim Sci 60:79-86

Gailer J (2009) Chronic toxicity of [As.sup.III] in mammals: the role of [(GS).sub.2][AsSe.sup.]. Biochimie 91:1268-1272

Gailer J, George GN, Pickering IJ, Prince RC, Ringwald SC, Pemherton JE (2000) A metabolic link between arsenite and selenite: the selenobis (S-glutathionyl) arsinium ion. J Am Chem Soc 122:46374639

Ganther HE, Hseih HS (1974) Mechanisms for the conversion of selenite to selenides in mammalian tissues. In: Trace Element Metabolism in Animals-2 (W.G. Hoekstra, Suttie, J.W., Ganther, H.E. and Mertz, W.; eds.), University Park Press, Baltimore, M.D. p 339

Gerloff BJ (1992) Effect of selenium supplementation on dairy cattle. J Anim Sci 70:3934-3940

Gresakova L, Cobanova K, Faix S (2013) Selenium retention in lambs fed diets supplemented with selenium from inorganic or organic sources. Small Ruminant Res 111:76-82

Hakkarainen J (1993) Bioavailability of selenium. Norwanian J Geol Suppl 11:21-35

Hansrad SL (1983) Microelements for ruminant animals - A review. Nutr Abstr Rev 53:1-24

Harrison JH, Conrad HR (1984) Effect of selenium intake on selenium utilization by the non-lactating dairy cow. J Dairy Sci 67:219-223

Hefnawy AEG, Tortora-Perez JL (2010) The importance of selenium and the effects of its deficiency in animal health. Small Ruminant Res 89:185-192

Khirwar SS, Arora SP (1976) Influence of different levels of selenium on protein synthesis in vitro. Milchwissenschaft 31:275-277

Kincaid, RL, Miller WJ, Neathery MW, Gentry RP, Hampton DL (1977) Effect of added dietary selenium on metabolism and tissue distribution of radioactive and stable selenium in calves. J Anim Sci 44:147-151

Koenig KM, Buckley WT, Shelford JA (1991) Measurement of endogenous faecal excretion and true absorption of selenium in dairy cows. Can J Anim Sci 71:167-174

Koenig KM, Rode LM, Cohen RDH, Buckley WT (1997) Effects of diet and chemical form of selenium on selenium metabolism in sheep. $\mathrm{J}$ Anim Sci 75:817-827

Krishnamurti CR, Ramberg CF, Shariff MA, Boston RC (1997) A compartmental

model depicting short-term kinetic changes in selenium metabolism in ewes fed hay containing normal or inadequate levels of selenium. $\mathrm{J}$ Nutr 127:95-102

Langlands JP, Bowles JE, Donald DE and Smith AJ (1986) Selenium excretion in sheep. Aust J Agric Res 37: 201-209

Levander OA (1977) Metabolic interrelationships between arsenic and selenium. Env Health Persp 19: 159-164

Martinez A, Church DC (1970) Effect of various mineral elements on in vitro rumen cellulose digestion. J Anim Sci 31:982-990

Massoumi A, Cornfield AH (1963) A rapid method for determining sulphate in water extracts of soils. Analyst 88:321-322

McDowell LR (1992) Minerals in Animals and Human Nutrition. Academic Press, New York, USA. p 294

Nadarinskaya MA (2003) The influence of selenium on homoeostasis and metabolism of high producing cows in winter. Zootechnical Science of Belarus Collection of Scientific Papers 38: 240-246

NRC (1980) Mineral Tolerance of Domestic Animals. National Academy Press. Washington, D.C., USA.

NRC (1983) Selenium in Nutrition. Rev. edn. National Academy of Sciences, Washington, D.C., USA DOI: https://doi.org/10.17226/40

NRC (2001) Nutrient Requirements of Dairy Cattle. $7^{\text {th }}$ rev. edn. National Academy of Sciences, Washington, DC., USA 
NRC (2005) Mineral Tolerance of Animals. $2^{\text {nd }}$ rev. edn. National Academy Press, Washington, D.C., USA

Peter DW, Buscall DJ, Young P (1986) Excretion, apparent absorption and retention of selenium from selenite and seleno-methionine by sheep. Proc Nutr Soc Aust 11:180

Peter DW, Whanger PD., Lindsay JP, Buscall DJ (1982) Excretion of selenium, zinc, copper by sheep receiving continuous intra-ruminal infusions of selenite or selenomethionine. Proc Nutr Soc Aust 7: $178-181$

Peter DW, Whanger PD (1986) Metabolism of selenite and selenomethionine by sheep. CSIRO Division of animal Production, Wembley, Western Australia

Pilsner JR, Hall MN, Liu X, Ahsan H, Ilievski V, Slavkovich V, Levy D, Factor-Litvak P, Graziano JH, Gamble MV (2011) Associations of plasma selenium with arsenic and genomic methylation of leukocyte DNA in Bangladesh. Env Health Persp 119:113-118

Podoll KL, Bernard JB, Ullrey DE, DeBar S.R, Ku P.K. and Magee W T. 1992. Dietary selenate versus selenite for cattle, sheep and horses. J Anim Sci 70:1965-1970

Prasad T and Arora S (1984) Influence of feeding high and low selenium rice straw on erythrocyte glutathione peroxidase activity and blood selenium concentration of buffalo calves. Indian J Animal Nutr 1:14

Prasad T and Arora SP (1991) Influence of different sources of injected selenium on certain enzymes, glutathionine and adenosyl methionine concentration in buffalo (Bubalus bubalis) calves. Br J Nutr 66:261267

Prasad T, Arora SP, Chopra RC (1982) Selenium toxicity as induced by feeding rice husk to buffalo calves. A clinical report. Indian Vet J 59:235-237

Sanz-Alaejos M, Diaz-Romero C (1993) Urinary selenium concentrations. Clini Chemica 39:2040-2052

Serra AB, Nakamura K, Matsui T, Harumoto T, Fujihara T (1994) Inorganic selenium for sheep. 1. Selenium balance and selenium levels in the different ruminal fluid fractions. Asian-Australas J Anim Sci 7:8389

Snedecor W, Cochran W (2007) Statistical Methods. $8^{\text {th }}$ edn. Iowa State University Press, Ames Iowa, USA

Spears JW (2003) Trace mineral bioavailability in ruminants. J Nutr 133: 1506-1509.

Sun XZ, Wang XP and Wang Y (1988) Effects of diets containing sulfur on the selenium metablism and immunological functions of the lymphatic organs of chicks. Chinese J Vet Sci Technol 11: 13-15

Tekchandani $\mathrm{N}$ and Arora SP. 1978. Incorporation of ${ }^{75} \mathrm{Se}-\mathrm{L}$ selenomethionine in rabbit tissue proteins and rumen microbial proteins in the cow. Indian J Dairy Sci 31:345-349.

Van Saun R.J (1990) Rational approach to selenium supplementation essential. Feedstuffs 15:15-17

Van Soest PJ, Robertson JB, Lewis BA (1991) Methods for dietary fiber, neutral detergent fiber, and non starch polysaccharides in relation to animal nutrition. J Dairy Sci 74:3583-3597

Vladimirov VL, Kirillov MP, Vinogadov VN, Kuznetsov Yu A, Badalov Ya M. 2003. Metabolism and productivity of cows fed concentrates with an organic form of selenium. Russian Agric Sci 11:17-20

Wang C, Liu Q, Yang WZ., Dong Q, Yang, XM, He D C, Zhang P, Dong KH, Huang YX (2009) Effects of selenium yeast on rumen fermentation, lactation performance and feed digestibilities in lactating dairy cows. Livestc Sci 126:239-244

Whanger D (1970) Sulfur-selenium relationships in animal nutrition. Sulphur Inst J 6:6-10.

Zanetti MA, Pettinati RL (1991) Selenium balance in sheep with and without supplementation of sodium selenite. Pesqui Agropecu Bras 26:455-460

Zeng H, Uthus EO, Combs GF Jr. (2005) Mechanistic aspects of the interaction between selenium and arsenic. J Inorg Biochem 99:12691274 